\title{
СТАН І ПЕРСПЕКТИВИ ФУНКЦОНУВАННЯ РИНКУ ЛІЗИНГОВИХ ПОСЛУГ У СІЛЬСЬКОМУ ГОСПОДАРСТВІ
}

Мета. Мета дослідження полягає у визначенні особливостей, проблем і перспектив функиіонування ринку лізингових послуг у сільському господарстві та його місия в розвитку лізингу в Україні.

Методологія / методика / підхід. Методологічною основою дослідження стали як загальнонаукові, так і спеціальні методи наукового пізнання. Було використано методи: монографічний, абстрактно-логічний, діалектичний, системно-структурний аналіз. Крім того, для досягнення поставленої мети використано системний підхід, методи інституціональної політичної економії, узагальнення, індукції, дедукції, аналізу, синтезу та порівняння.

Результати. У статті грунтовно досліджено питання розвитку ринку лізингових послуг в Україні, здійснено аналіз тенденцій його розвитку. Узагальнено особливості лізингу як виду економічної діяльності, щзо впливають на його розвиток і поширення. Визначено, щуо найбільш активно застосування лізингових операцій відбувається в сільському господарстві й транспортній сфері. Установлено, що основними гравиями на ринку послуг фінансового лізингу залишаються юридичні особи лізингодавиі, десять найбільших із них формують до $80 \%$ портфеля чинних договорів. За умови збереження тренду до зростання вартості лізингового портфеля, у 2020 р. вартість договорів фінансового лізингу в аграрному виробництві України може збільшитися до 8192,6млн грн. Визначено, щзо лізингове кредитування $\epsilon$ поширеним способом формування матеріально-технічної бази сільськогосподарського виробництва, воно забезпечує підвищення продуктивності виробництва, сприяє модернізачіі агробізнесу та підвищенню конкурентоспроможності продукиї, підприємств і галузі в цүілому.

Оригінальність / наукова новизна. Наукова новизна полягає у визначенні співвідношення динаміки зміни вартості договорів фінансового лізингу укладених у сільському господарстві з показником валового внутрішнього продукту, та розробиі математичних функиій, що описують зміну зазначених показників. Дістало дальшого розвитку обгрунтування місия сільського господарства на ринку послуг фінансового лізингу.

Практична цінність / значущість. Практична цінність иієї статті полягає в тому, щзо одержані автором теоретичні узагальнення сприятимуть формуванню уявлень про стан $і$ перспективи розвитку ринку лізингових послуг в Україні та місце сільського господарства в ньому. Розроблені функиії екстраполяиії вартості договорів фінансового лізингу галузі та валового внутрішнього продукту можуть бути використані в прочесі поточного планування діяльності.

Ключові слова: лізинг, ринок лізингових послуг, лізинг у сільському господарстві, фінансовий лізинг, лізингодавещь, лізингоотримувач. 


\section{Kharkiv National Agrarian University named after V. V. Dokuchayev \\ Ukraine}

\section{STATE AND PROSPECTS OF FUNCTIONING OF THE MARKET OF LEASING SERVICES IN AGRICULTURE}

Purpose. The purpose of the study is to determine the features, problems and prospects of the market of leasing services in agriculture and its place in the development of leasing in Ukraine.

Methodology / approach. The methodological basis of the study was both general and special methods of scientific knowledge. The following methods were used: monographic, abstract-logical, dialectical, system-structural analysis. In addition, a systemic approach, methods of institutional political economy, generalization, induction, deduction, analysis, synthesis and comparison were used to achieve this purpose.

Results. The article thoroughly investigates the development of the leasing services market in Ukraine, analyzes the trends of its development. The peculiarities of leasing as a type of economic activity that affect its development and spread are generalized. It is determined that the most active use of leasing operations is in agriculture and transport. It is established that the main players in the market of financial leasing services are legal entities lessors, the ten largest of them form up to $80 \%$ of the portfolio of existing contracts. If the trend to increase the value of the leasing portfolio is maintained, in 2020 the value of financial leasing agreements in Ukrainian agriculture may increase to $8192.6 \mathrm{mln}$ UAH. It is determined that leasing is a common way to form the materialand-technical base of agricultural production, it increases the productivity, helps to modernize of agribusiness and increase the competitiveness of products, enterprises and the industry as a whole.

Originality / scientific novelty. The scientific novelty is to determine the ratio of the dynamics of changes in the value of financial leasing agreements concluded in agriculture with an indicator of gross domestic product, and the development of mathematical functions that describe the change in these indicators. The substantiation of the place of agriculture in the market of financial leasing services was further developed.

Practical value / implications. The practical value of this article is that the theoretical generalizations obtained by the author will contribute to the formation of ideas about the state and prospects of the leasing services market in Ukraine and the place of agriculture in it. The developed functions of extrapolation of the value of financial leasing agreements of the industry and gross domestic product can be used in the current planning process.

Key words: leasing, leasing services market, leasing in agriculture, financial leasing, lessor, lessee.

Постановка проблеми. Стан матеріально-технічної бази аграрних підприємств є запорукою високого рівня їхньої конкурентоспроможності й ефективності господарської діяльності. В умовах прискореного розвитку інноваційних технологій i дефіциту фінансових ресурсів, вирішення питань фінансового забезпечення інноваційно-технологічного розвитку аграрних підприємств України набуває особливої актуальності [1-4].

Лізинг - один із найістотніших шляхів матеріально-технічного забезпечення і $є$ прискорювачем темпів виробництва сільськогосподарськими товаровиробниками продукції, засобом сприяння економічному розвитку 


\section{Agricultural and Resource Economics}

www.are-journal.com

аграрного виробництва. Сільському господарству в Україні вкрай складно розвиватися без лізингу як джерела кредитування капіталовкладень. На вітчизняному ринку основним видом лізингової діяльності $є$ фінансовий лізинг, оскільки клієнти здебільшого зацікавлені в отриманні предмета лізингу у власність наприкінці дії договору лізингу.

Аналіз останніх досліджень і публікацій. Фінансовий лізинг належить до числа перспективних фінансових інструментів, який зазвичай є цікавим як для лізингодавця, так i для лізингоотримувача. Дослідженню питань функціонування ринку лізингових послуг присвячено велику кількість наукових праць, які охоплюють вивчення як теоретичних, так і практичних аспектів лізингової діяльності в Україні [5-7]. Стан, законодавче регулювання й перспективи розвитку фінансового лізингу в деяких європейських країнах, а також у Китаї та США, грунтовно висвітлено в працях A. Frignani, M. Torsello [8], M. M. Inceoğlu, B. Başoğlu [9], T. Josipović, W. Wang [10], P. W. Schroth [11], S. Han, W. Wang [12], P. Goeringer [13].

Питання перешкод, перспектив та можливостей розвитку галузі частково знайшли своє відображення в працях М. М. Дученко та Т. В. Павленко [14], О. Васильчишин, О. Тулай [15], Н. С. Ситник, Д. О. Корень [16]. Колективом авторів у складі Т. А. Васильєвої, А. О. Бойко, А. В. Кіріл'євої виявлено перспективи розвитку вітчизняного ринку лізингових послуг у контексті трансформації фінансових відносин в Україні [17] та обгрунтовано роль лізингу в процесах фінансово-кредитного забезпечення підприємств [18]. Роль i розвиток лізингу в сільському господарстві досліджують учені І. В. Черевань [19], В. В. Іванишин [20; 21], М. Я. Дем'яненко [22], Т. Н. Літвінова [23]. Цінні пропозиції щодо вдосконалення наявного механізму фінансового лізингу на основі державної фінансової підтримки екологічно орієнтованих підприємств 3 використанням рівня навантаження на наявну працездатну техніку запропоновано в статті П. Пивовара, О. Чайкіна, Д. Дідуха [24].

Але, незважаючи на велику кількість напрацювань і наявність грунтовного методичного та методологічного інструментарію вивчення й здійснення лізингової діяльності, зазначені питання потребують дальшого дослідження, актуальність якого зростає з урахуванням плинності часу, розвитку науки й техніки і трансформації економічних відносин.

Мета статті полягає у визначенні особливостей, проблем і перспектив функціонування ринку лізингових послуг у сільському господарстві та його місця в розвитку лізингу в Україні.

Виклад основного матеріалу дослідження. Лізинг у теперішніх умовах здійснення господарської діяльності набуває все більшої популярності, що пов’язано з притаманними йому відомими особливостями, а саме:

- інвестування у формі майна, на відміну від грошового кредиту, знижує ризик неповернення коштів, оскільки за лізингодавцем зберігаються права власності на передане майно;

- лізингові операції дозволяють здійснювати інноваційну діяльність тим 
підприємствам, які не мають власних коштів або володіють недостатньою їхньою сумою, оскільки лізингове майно виступає в ролі застави;

- лізингова угода більш гнучка, ніж позика, оскільки дозволяє обом сторонам сформувати зручну схему виплат;

- для лізингоодержувача зменшується ризик морального й фізичного старіння майна, оскільки його не купують у власність, а беруть у тимчасове користування. Під час лізингових відносин лізингоодержувач має справу 3 прискореною амортизацією майна;

- лізинг дає можливість розширеного відтворення та інтенсифікації діяльності малих і середніх суб'єктів господарювання, які не мають власних коштів для придбання необхідних ресурсів і стикаються 3 проблемами із залученням кредитних коштів;

- лізингове майно не обліковують у лізингоодержувача на балансі, що не збільшує його активи й звільняє від сплати податку на це майно; крім того, лізингові платежі відносять до витрат виробництва (собівартості) лізингоодержувача, що відповідно знижує суму оподаткованого прибутку.

Нині розвиток лізингового кредитування - стратегічний напрям дій державних органів влади, адже лізинг надає великі можливості для виходу 3 кризи національної економіки та удосконалення господарської діяльності суб'єктів аграрного бізнесу.

За словам Т. А. Васільєвої зі співавторами, перспективи розвитку вітчизняного ринку лізингових послуг визначаються функціями лізингу. Основними з них автори вбачають такі:

-виробнича, яка передбачає оперативне розв'язання проблем технічного переоснащення виробництва, забезпечуючи доступ підприємства до нової техніки й технологій;

-фінансова, завдяки якій можна надавати основні фонди в користування на умовах кредиту, а також використовувати податкові й амортизаційні пільги;

-збутова, що має на меті стимулювати просування продукції й сприяти освоєнню нових сегментів ринку [17].

Пояснюючи причини активного розвитку лізингових операцій у світовій практиці за останні 15-20 років, В. І. Захарченко та ін. звертають увагу на:

- швидке моральне старіння техніки;

- зростання конкуренції. Підприємствам, які розпочинають свою справу, дуже складно зайняти свою ринкову нішу, тому $\epsilon$ потреба в таких маркетингових способах, які дали б можливість клієнтам на практиці ознайомитися із зразками техніки, що виготовляють. Пропонуючи її в лізинг на певний термін, виробник нерідко бере на себе зобов'язання зі встановлення й обслуговування обладнання та навчання персоналу;

- збільшення кількості капіталомістких проєктів;

- економія коштів підприємств-споживачів, особливо невеликих за розмірами (дешевше орендувати обладнання, ніж придбати його за повну 
вартість) [25, с. 340-350].

За даними асоціації «Українське об’єднання лізингодавців», лізинговий ринок України продовжує зростати високими темпами п'ятий рік поспіль, значно випереджаючи темпи зростання українського ВВП. Малий і середній бізнес відчуває особливо велику потребу в оновленні виробничих потужностей. В умовах обмеженого банківського кредитування лізинг стає майже безальтернативним джерелом фінансування модернізації. Відповідно до прогнозів учасників асоціації, за умови підвищення обізнаності підприємців про можливості лізингу, поліпшення фінансової грамотності представників бізнесу, обсяги лізингових угод істотно зростатимуть і надалі [26].

Згідно із чинним законодавством, послуги фінансового лізингу можуть надавати банки та інші небанківські установи, внесені до реєстру фінансових установ, який веде Національна комісія, що здійснює державне регулювання у сфері ринків фінансових послуг (Нацкомфінпослуг). Станом на 01.01.2020 p. право на надання послуг фінансового лізингу в Україні, на підставі ліцензії, виданої Національною комісією фінансових послуг, мали 113 юридичних осіб лізингодавців і 439 фінансових компаній (табл. 1).

Таблиця 1

Розвиток фінансового лізингу в Україні

\begin{tabular}{|c|c|c|c|c|c|c|}
\hline \multirow[b]{2}{*}{ Показники } & \multicolumn{5}{|c|}{ Роки } & \multirow{2}{*}{$\begin{array}{l}2019 p . \\
\text { у \% до } \\
2015 p .\end{array}$} \\
\hline & 2015 & 2016 & 2017 & 2018 & 2019 & \\
\hline $\begin{array}{l}\text { Загальна кількість осіб- } \\
\text { лізингодавців, усього }\end{array}$ & 630 & 630 & 463 & 505 & 552 & 87,6 \\
\hline у т.ч.: юридичні особи-лізингодавці & 268 & 202 & 183 & 116 & 113 & 42,2 \\
\hline $\begin{array}{l}\text { фінансові компанії, що надають } \\
\text { послуги фінансового лізингу } \\
\text { (фізичні особи) }\end{array}$ & 362 & 428 & 280 & 389 & 439 & 121,3 \\
\hline $\begin{array}{l}\text { Вартість укладених договорів } 3 \\
\text { розрахунку на } 1 \text { лізингодавця, млн } \\
\text { грн, усього: }\end{array}$ & 9,9 & 15,6 & 28,0 & 43,9 & 47,5 & y $4,8 p$. \\
\hline у т. ч.: юридичні особи & 23,3 & 48,3 & 70,0 & 185,5 & 218,1 & y $9,5 \mathrm{p}$. \\
\hline фізичні особи & 0,06 & 0,16 & 0,55 & 1,73 & 3,64 & y $65,2 \mathrm{p}$ \\
\hline $\begin{array}{l}\text { Кількість укладених договорів } 3 \\
\text { розрахунку на } 1 \text { лізингодавця, } \\
\text { усього: }\end{array}$ & 6,5 & 14,5 & 16,7 & 20,4 & 28,1 & $\mathrm{y} 4,3 \mathrm{p}$. \\
\hline у т. ч.: юридичні особи & 15,3 & 45,2 & 42,1 & 75,3 & 109,4 & y 7,2 p. \\
\hline фізичні особи & 0,1 & 0,1 & 0,2 & 4,1 & 7,1 & - \\
\hline $\begin{array}{l}\text { Частка лізингодавців у загальній } \\
\text { вартості чинних договорів } \\
\text { фінансового лізингу: } \\
\text { юридичні особи }\end{array}$ & 99,7 & 99,3 & 98,8 & 97,0 & 93,9 & $-5,8$ в.п. \\
\hline фізичні особи & 0,3 & 0,7 & 1,2 & 3,0 & 6,1 & 5,8 в.п. \\
\hline
\end{tabular}

Джерело: розраховано автором за даними Нацкомфінпослуг України.

Незважаючи на стрімке збільшення кількості фінансових компаній, що надають послуги фінансового лізингу (більш ніж на 20,0 \%), їхня частка у 


\section{Agricultural and Resource Economics}

www.are-journal.com

вартості чинних договорів залишається незначною i має тенденцію до збільшення 3 0,3\% до 6,1\%. Тобто основними гравцями на ринку послуг фінансового лізингу залишаються юридичні особи-лізингодавці, адже кількість укладених договорів із розрахунку на одну 3 них у 2019 р. становила 109 одиниць із середньою вартістю договору 1993,6 тис. грн. 3 розрахунку на одну фізичну особу-лізингодавця укладено сім договорів за рік із середньою вартістю 513 грн.

При цьому 93,4\% лізингових послуг припадає на 20 найбільших юридичних осіб - лізингодавців, трійка лідерів ринку лізингових послуг формувала майже 60 \% портфелю чинних договорів станом на 31.12.2019 p.

Характерними є зміни й у строковості лізингових договорів, а саме спостерігається тенденція збільшення частки довгострокових договорів фінансового лізингу. Вартість договорів, термін дії яких менше або дорівнює двом рокам, порівняно з попереднім роком, зменшилася на 10,0 \%, тоді як строком від 2 до 5 років - збільшилася на 35,2 \%, що становить 5111,4 млн грн). Тенденцію до збільшення має i вартість договорів із терміном дії більше 10 років - у 1,2 раза (944,1 млн грн) [27].

У розрізі галузей, найбільшими користувачами лізингових послуг $\epsilon$ транспорт і сільське господарство. Якщо частка транспорту в загальній вартості чинного лізингового портфелю протягом останніх п’яти років має стійку тенденцію до зменшення (на 12 відсоткових пунктів), то сільське господарство у 2019 р. споживало майже 19,0 \% послуг фінансового лізингу (табл. 2).

Табличя 2

Питома вага вартості чинних договорів фінансового лізингу за галузями (станом на 31.12.2019 р.), \%

\begin{tabular}{|c|c|c|c|c|c|c|}
\hline \multirow{2}{*}{ Галузі } & \multicolumn{5}{|c|}{ Роки } & \multirow{2}{*}{$\begin{array}{c}\text { Відхилення } \\
(+,-), \\
\text { відсоткових } \\
\text { пунктів }\end{array}$} \\
\hline & 2015 & 2016 & 2017 & 2018 & 2019 & \\
\hline Будівництво & 6,11 & 3,68 & 4,24 & 4,40 & 3,89 & $-2,22$ \\
\hline Добувна промисловість & 6,97 & 6,53 & 0,67 & 3,02 & 2,79 & $-4,18$ \\
\hline Легка промисловість & 0,17 & 0,11 & 0,03 & 0,02 & 0,03 & $-0,14$ \\
\hline Машинобудування & 1,30 & 1,16 & 1,06 & 0,90 & 0,83 & $-0,48$ \\
\hline Металургія & 0,48 & 0,33 & 1,92 & 3,73 & 1,80 & 1,31 \\
\hline Сільське господарство & 13,31 & 22,44 & 22,21 & 19,53 & 18,73 & 5,42 \\
\hline Сфера послуг & 3,93 & 4,79 & 5,45 & 6,10 & 6,24 & 2,31 \\
\hline Транспорт & 32,93 & 31,30 & 29,14 & 25,42 & 21,07 & $-11,86$ \\
\hline Харчова промисловість & 2,13 & 1,70 & 1,22 & 2,27 & 3,73 & 1,59 \\
\hline Хімічна промисловість & 1,08 & 0,50 & 0,47 & 0,57 & 0,43 & $-0,66$ \\
\hline Медичне обслуговування & 0,12 & 0,07 & 0,07 & 0,44 & 0,38 & 0,25 \\
\hline $\begin{array}{l}\text { Комп'ютерна та } \\
\text { телекомунікаційна сфера }\end{array}$ & 0,04 & 0,01 & 0,03 & 0,40 & 0,50 & 0,47 \\
\hline Переробна промисловість & 0,27 & 0,28 & 0,17 & 0,35 & 2,21 & 1,95 \\
\hline Інше & 23,11 & 19,10 & 25,15 & 25,46 & 30,88 & 7,77 \\
\hline
\end{tabular}

Джерело: розраховано автором за даними Нацкомфінпослуг України. 


\section{Agricultural and Resource Economics}

www.are-journal.com

Крім того, зміни відбулися й у добувній промисловості, адже часка галузі у вартості договорів фінансового лізингу на кінець 2019 р. становила 2,8 \%, що на 4,2 відсоткових пунктів менше значення 2015 р., який обрано за базу порівняння. Лізингова діяльність набула розповсюдження у сфері послуг, адже частка галузі у вартості лізингового портфеля зросла з 3,9 \% до 6,2 \%.

Найменшими споживачами лізингових послуг $\epsilon$ легка й хімічна промисловості та медичне обслуговування (для прикладу, вартість укладених договорів фінансового лізингу у 2019 р. у легкій промисловості становила 10,0 млн грн, у той час як для транспортної галузі - понад 6,5 млрд грн).

Протягом 2019 р. найчастіше в лізинг фінансувалися такі предмети:

- транспортні засоби - 16450 млн грн або $63 \%$ від загальної суми договорів;

- техніка, машини та устаткування для сільського господарства 6701 млн грн $(25,5 \%)$;

- будівлі та споруди - 1109 млн грн або 4 \% від загальної суми договорів;

- будівельне обладнання й техніка - 1069 млн грн або 4 \% від загальної суми договорів [28].

Лізингове кредитування $є$ поширеним способом формування матеріальнотехнічної бази сільськогосподарського виробництва в усьому світі. Воно забезпечує підвищення продуктивності машин й обладнання, сприяє модернізації виробництва та підвищенню конкурентоспроможності продукції, підприємств і галузі в цілому.

Аналізуючи динаміку вартості лізингового портфеля сільського господарства у період 2010-2019 pр., доцільно звернути увагу на циклічний характер зміни показника (рис. 1).

Чітко простежується період активізації лізингової діяльності до 2014 р., включно, коли досліджуваний показник становив найбільше значення, а саме 11,2 млдр грн. Наступним $\epsilon$ період спаду, який тривав чотири роки - до 2018 p. i мінімальна вартість договорів фінансового лізингу, що діяли на кінець звітного періоду становила 5,3 млдр грн. Починаючи 32019 р. відбувається незначне зростання досліджуваного показника, що підтверджується й розробленим рівнянням параболи третього порядку в результаті вирівнювання динамічного ряду вартості лізингового портфеля, достовірність якого є досить високою, адже коефіцієнт детермінації становить 0,7895. Установлено, що за умови збереження тенденції до зростання вартості лізингового портфеля, у 2020 р. вартість договорів фінансового лізингу в аграрному виробництві України може збільшитися до 8192,6 млн грн, що, 3 огляду на фактичні показники лізингового фінансування у 2012-2014 pp., $\epsilon$ цілком можливим.

Валовий внутрішній продукт $є$ одним із найважливіших показників розвитку економіки, що характеризує кінцевий результат виробничої діяльності економічних одиниць-резидентів у сфері матеріального й нематеріального виробництва. Він $є$ найбільш поширеним показником, який використовують 


\section{Agricultural and Resource Economics \\ www.are-journal.com}

для того, щоб зробити висновок про рівень економічного розвитку країни або галузі. Саме цей показник нами використано 3 метою дослідження взаємозв'язку між вартістю фінансового лізингового портфеля в сільському господарстві та результативним показником господарської діяльності.

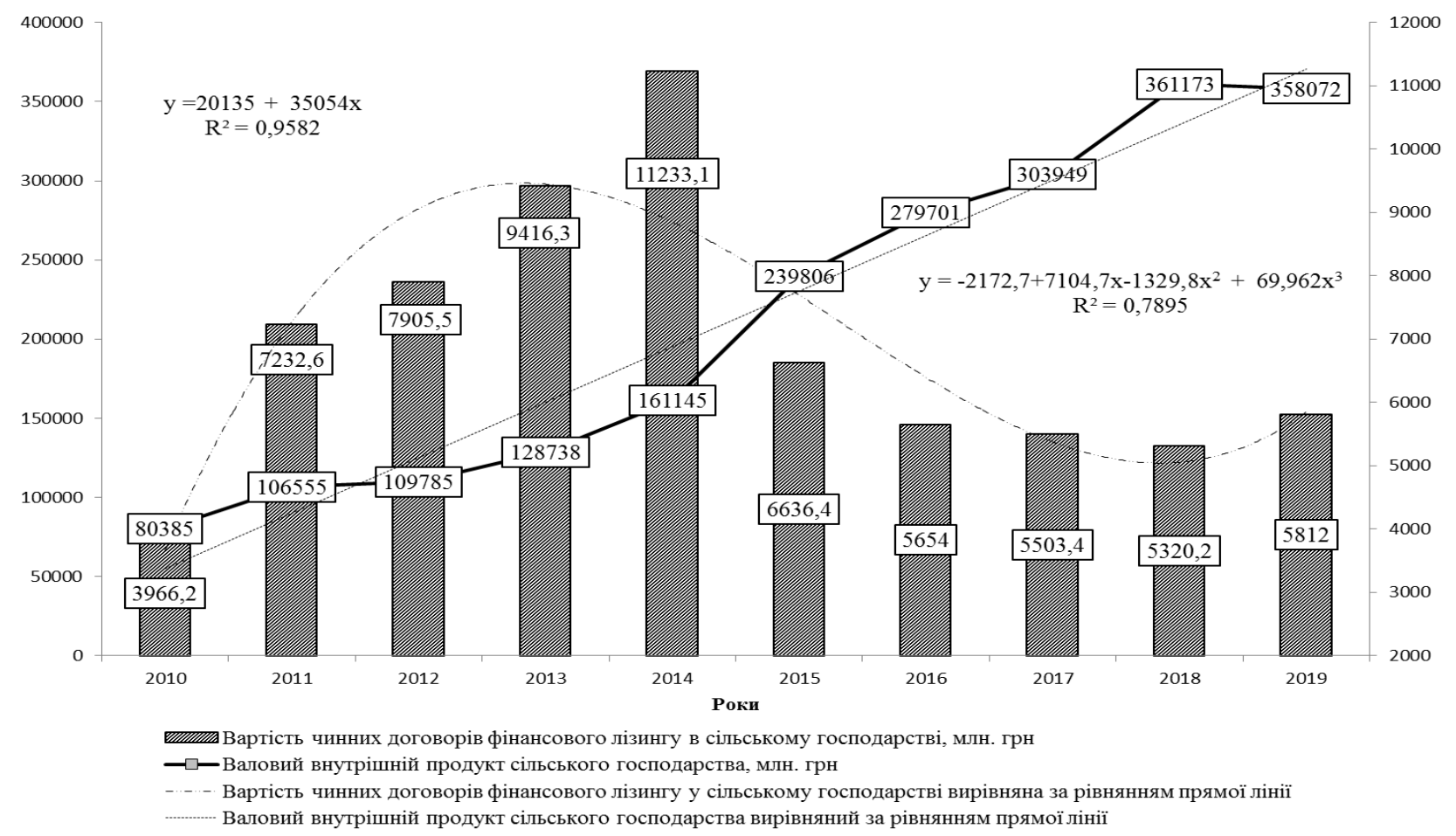

Рис. 1. Вирівнювання динамічного ряду вартості лізингового портфеля та валового внутрішнього продукту сільського господарства в Україні

Джерело: розраховано й побудовано автором за даними Державної служби статистики України та Нацкомфінпослуг України.

Отже, протягом досліджуваного періоду відбувалося зростання валового внутрішнього продукту сільського господарства в середньому на 35 млдр грн щороку, про що свідчить розраховане рівняння на основі вирівнювання динамічного ряду з імовірністю 95,8 \%. Певною мірою це пояснюється тим, що найчастіше в лізинг фінансується придбання техніки, машин та устаткування для сільського господарства, тобто основні засоби. Їх строк корисного використання великий, а максимальна віддача, інколи, досягається через кілька років використання. Саме тому розрахований коефіцієнт парної кореляції між досліджуваними показниками становить 0,36, що свідчить про незначну залежність між ними.

Незважаючи на значне розширення лізингової діяльності в сільському господарстві останніми роками, не всі суб'єкти господарювання у повній мірі охоплені нею, адже переважна кількість договорів фінансового лізингу укладається 3 юридичними особами (близько 50,0\% у 2019 р.), а решта - 3 фізичними особами та фізичними особами підприємцями [26].

До основних перешкод для розвитку фінансового лізингу дослідники Н. С. Ситник та Д. О. Корень відносять: обмеженість фінансування галузі, відсутність сприятливої нормативно-правової бази, відсутність спеціальних 


\section{Agricultural and Resource Economics}

www.are-journal.com

податкових стимулів, низька обізнаність підприємців про сучасні інструменти фінансування бізнесу [16]. Крім того, до факторів, які не сприяють розвитку ефективних лізингових відносин, доцільно віднести дефіцит капіталу та джерел його формування. Адже в більшості випадків лізингова діяльність здійснюється за рахунок коштів банківських структур та інших фінансових посередників, що надають їх під високий відсоток, збільшуючи при цьому вартість лізингових послуг для лізингоодержувачів. Варто погодитися 3 думкою вчених, що в Україні не вистачає великих мереж міжнародних банків і лізингових компаній. Водночас ті компанії, що належать до складу банківських груп, і теоретично могли б мати необмежене фінансування від материнської банківської структури, повинні дотримуватися вимог Національного банку України, що обмежує фінансування до $25 \%$ статутного капіталу суб'єкта в структурі компаній, що належать до тієї самої групи [14].

Однак поряд із перевагами лізинг як інструмент запровадження інновацій має низку вад. До них вчені відносять такі:

- надто складна процедура лізингової угоди через значну кількість учасників, на підготовку фінансової лізингової угоди затрачають значно більше часу, ніж на підготовку контракту на купівлю;

- вищі адміністративні витрати (ціна лізингу може бути нижчою або дорівнювати ціні позики лише за наявності певних податкових пільг);

- умови укладення договору лізингу вимагають перебування на обліку в Державній комісії з регулювання ринків фінансових послуг, що особливо складно для окремих підприємств;

- лізингові операції із невеликими аграрними підприємствами є досить ризикованими для лізингодавця через відсутність чіткої державної політики із стимулювання інвестицій у сільське господарство [29].

Незважаючи на вади лізингової діяльності, запровадження та поширення лізингових схем у сільському господарстві $\epsilon$ надзвичайно важливим для відродження та стабілізації функціонування агропромислового комплексу в цілому та всіх його складових частин. Основними факторами ризику фінансового лізингу в сільському господарстві можуть бути: сезонний характер виробництва; тривалий виробничий цикл; вплив природно-кліматичних умов на результати діяльності; велика строкатість показників якості продукції та складність контролю за ними тощо.

У майбутньому підвищення активності ринку лізингових послуг можна очікувати за рахунок аграрної промисловості, яка останнім часом демонструє стійкі тенденції до зростання та, відповідно, потребує додаткових інвестиційних ресурсів. Збільшення обсягів фінансування предметів лізингу має відбуватися як за рахунок істотної активізації роботи із суб'єктами, які раніше здобули досвід роботи 3 лізинговими компаніями, так і за рахунок налагодження якіснішої співпраці 3 представниками малого та середнього бізнесу [28].

3 метою практичної демонстрації переваг фінансового лізингу нами 


\section{Agricultural and Resource Economics \\ www.are-journal.com}

виконано модельний розрахунок придбання в лізинг обладнання на прикладі трактора та борони. Вивчення та зіставлення даних, щодо умов надання лізингу сільськогосподарської техніки та обладнання свідчить, що найвигідніше укладати лізингові угоди, 3 погляду лізингоодержувача, 3 Національною акціонерною компанією (НАК) «Украгролізинг». Однією з важливих переваг пропонованої компанією схеми продажу на умовах лізингу є авансовий платіж у розмірі $15 \%$ від вартості техніки, що купується, тоді як в інших компаній він коливається від 20 до 50 \%. Відсоткова ставка, що нараховується на залишок платежу, становить у НАК «Украгролізинг» $3,5 \%$ річних у гривнях.

Нині НАК «Украгролізинг» - одна $з$ найпотужніших компаній України, яка має великий досвід у сфері інвестування коштів в агропромисловий комплекс країни. Порядок надання техніки в лізинг НАК «Украгролізинг» зводиться до таких етапів: вибір техніки або обладнання; оформлення заявки та надання документів згідно 3 переліком; укладання договору фінансового лізингу; укладання договору застави; отримання об'єкта лізингу та його страхування.

Строк, на який передаються об’єкти фінансового лізингу, коливається від трьох до семи років, обов'язковим $є$ укладання договору застави або поруки на суму, не меншу двох чергових платежів. Попередній платіж включає в себе $15 \%$ вартості об'єкта лізингу та 7 \% від його невідшкодованої вартості, що становить винагороду лізингодавцю. Чергові платежі сплачують два рази на рік i складаються із вартості об'єкта та плати лізингодавцю (7\% річних від невідшкодованої вартості). Ці умови враховано під час розрахунку лізингових платежів для колісного трактора загального призначення ХТЗ-242К та борони дискової Паллада 2400 для модельного аграрного підприємства (табл. 3).

\section{Розрахунок лізингових платежів за обладнання для аграрного підприсмства (за умови отримання об'єкта лізингу в НАК «Украгролізинг»)}

\begin{tabular}{|c|c|c|}
\hline \multicolumn{1}{|c|}{ Показники } & Сума, грн & $\begin{array}{c}\text { У \% до } \\
\text { залальної суми } \\
\text { лізингових } \\
\text { платежів }\end{array}$ \\
\hline \multicolumn{2}{|c|}{ Колісний трактор загального призначення ХТЗ-242К } \\
\hline Вартість об’єкта лізингу & 1734000 & х \\
\hline Винагорода лізингодавцю & 246228 & 14,2 \\
\hline Загальна сума лізингових платежів & 1980228 & 100,0 \\
\hline У тому числі: попередні лізингові платежі & 362382 & 18,3 \\
\hline поточні лізингові платежі & 1617846 & 81,7 \\
\hline \multicolumn{2}{|c|}{ Борона дискова Паллада 2400 (БДН 2400) } \\
\hline Вартість об’єкта лізингу & 95000 & х \\
\hline Винагорода лізингодавцю & 13490 & 14,2 \\
\hline Загальна сума лізингових платежів & 108490 & 100,0 \\
\hline У тому числі: попередні лізингові платежі & 19854 & 18,3 \\
\hline поточні лізингові платежі & 88636 & 81,7 \\
\hline
\end{tabular}

Джерело: розраховано автором за умовами лізингу НАК «Украгролізинг». 


\section{Agricultural and Resource Economics}

www.are-journal.com

Так, за умови вартості трактора ХТЗ-242К 1734,0 тис. грн винагорода лізингодавця становитиме 246228 грн, що дорівнюе $14,2 \%$ загальної суми лізингових платежів. Водночас сума попередніх платежів буде становити 362382 грн, тобто 18,3\%, це $є$ дуже важливим моментом, адже авансовий платіж (або «перший внесок») має велике значення для лізингоодержувачів, які часто є економічно слабкими суб'єктами господарювання. У результаті усіх передбачених виплат загальна вартість об'єкта лізингу становитиме 1980,2 тис. грн. Аналогічні розрахунки лізингових платежів стосовно борони дискової Паллада 2400 дозволяють зазначити про збільшення вартості об'єкта лізингу на $14,2 \%$, що можна вважати прийнятним 3 позиції вартості для лізингоодержувачів, зокрема порівняно з банківськими кредитами та рівнем річної інфляції, який фіксується впродовж останніх років.

Для створення більшої доступності лізингу для аграрних підприємств як за рахунок коштів Державного бюджету, так й інших суб'єктів господарювання, О.В. Гудима пропонує повністю скасувати авансові платежі й установити термін розрахунків за лізинговим договором для комбайнів і тракторів - до 8 років, а для інших об'єктів - до 5 років. При цьому постачальницько-збутова націнка від вартості предмета лізингу не повинна перевищувати для комбайнів і тракторів $5 \%$, а для інших об'єктів - $7 \%$. Запропоновано упровадити щорічну періодичність платежів, починаючи з кінця другого року, а розмір винагороди $3 \%$ від невідшкодованої вартості предмета лізингу. Для захисту прав лізингодавця варто запровадити обов'язкове страхування в розмірі 2,5\% вартості предмета лізингу на весь термін дії договору лізингу [30, с. 11].

Отже, варто зазначити, що не тільки сільськогосподарські підприємства але й держава має бути зацікавлена в розвитку лізингу, оскільки він $\epsilon$ інвестиційним механізмом, що сприяє оновленню техніки й технологій, зростанню конкурентоспроможності, зменшенню енерго- та матеріаломісткості виробництва, зростанню екологічної й технічної безпеки виробництва, поліпшенню умов праці, розвитку малого та середнього агробізнесу та сільських територій, підвищенню ефективності виробництва та добробуту населення, зростанню бюджетних надходжень.

Висновки. Лізинг одночасно має бути одним із механізмів перерозподілу тимчасово вільного капіталу, сприяти ефективному його використанню й інструментом оновлення матеріально-технічної бази підприємств, удосконалення їхньої інноваційної та інвестиційної діяльності. Саме особливості лізингу порівняно 3 кредитними та орендними відносинами забезпечують його популярність і зростаючий попит. Роль розвитку лізингових послуг у сільському господарстві зумовлюється особливостями галузі, а саме високим рівнем ризиків діяльності, впливом природно-кліматичних умов та сезонності господарської діяльності.

В Україні найбільш поширеним є фінансовий лізинг, який обов'язково потребує ліцензування діяльності. Останніми роками характерним є збільшення кількості ліцензованих фізичних осіб, однак їхня частка у вартості чинних 


\section{Agricultural and Resource Economics}

www.are-journal.com

договорів залишається незначною, основними гравцями на ринку послуг фінансового лізингу є юридичні особи-лізингодавці: десять найбільших із них формують до 80 \% портфеля чинних договорів.

Сільське господарство належить до числа найбільших користувачів лізингових послуг, 3 притаманним йому зростанням питомої ваги вартості чинних договорів у загальній їх сумі. Динаміка показників вартості лізингового портфеля в аграрній галузі залежить від економічної, політичної та правової ситуації в країні й має циклічні коливання, що підтверджено розробленим рівнянням параболи третього порядку й розрахованим коефіцієнтом детермінації. За умови збереження тренду до зростання вартості лізингового портфеля, у 2020 р. вартість договорів фінансового лізингу в аграрному виробництві України може збільшитися до 8192,6 млн грн, що, з огляду на фактично досягнуті показники в попередні роки, є цілком можливим.

Перспективним напрямом дальших досліджень функціонування ринку лізингових послуг у сільському господарстві $є$ виявлення принципів розподілу лізингового портфеля між учасниками ринку та його впливу на формування результативних показників аграрного підприємства та галузі в цілому.

\section{Список використаних джерел}

1. Davidenko N., Skrypnyk H., Titenko Z., Zhovnirenko O. V. Modeling of the optimum level of financial provision of Ukrainian enterprises' innovative activities. Global Journal of Environmental Science and Management. 2019. Vol. 5. Spec. is. Pp. 197-205. https://doi.org/10.22034/gjesm.2019.05.SI.22.

2. Kirieieva E. A., $\quad$ Pryshliak N. V., Shamanska O. I., Salkova I. Yu. Kucher A. V. Strategic priorities and financial support of Ukrainian agricultural sector development. International Journal of Ecological Economics \& Statistics. 2019. Vol. 40. No. 2. Pp. 25-37.

3. Pronko L., Furman I., Kucher A., Gontaruk Y. Formation of a state support program for agricultural producers in Ukraine considering world experience. European Journal of Sustainable Development. 2020. Vol. 9. No. 1. Pp. 364-379. https://doi.org/10.14207/ejsd.2020.v9n1p364.

4. Sakhno A., Polishchuk N., Salkova I., Kucher A. Impact of credit and investment resources on the productivity of agricultural sector. European Journal of Sustainable Development. 2019. Vol.8. No. 2. Pp. 335-345. https://doi.org/10.14207/ejsd.2019.v8n2p335.

5. Внукова Н. Н. Сучасний стан економіко-правового регулювання фінансового лізингу в Україні. Лізинг в Україні. 2005. № 3. С. 8-10.

6. Саблук Р. П. Теоретичні аспекти лізингових відносин. Економіка АПК. 2000. № 11. С. 49-57.

7. Кузнецова А. Я., Левченко О. А. Методичні підходи до класифікації лізингу. Фінансово-кредитна діяльність: проблеми теорії та практики. 2017. T. 1. № 22. C. 19-26. https://doi.org/10.18371/fcaptp.v1i22.109735.

8. Frignani A., Torsello M. Financial leasing in Italy. Uniform Law Review. 2011. Vol. 16. Is. 1-2. Pp. 351-371. https://doi.org/10.1093/ulr/16.1-2.351. 


\section{Agricultural and Resource Economics}

www.are-journal.com

9. Inceoğlu M. M., Başoğlu B. Financial leasing in Turkey in light of recent developments. Uniform Law Review. 2011. Vol. 16. Is. 1-2. Pp. 415-435. https://doi.org/10.1093/ulr/16.1-2.415.

10. Josipović T., Wang W. Financial leasing in Croatia. Uniform Law Review. 2011. Vol. 16. Is. 1-2. Pp. 271-289. https://doi.org/10.1093/ulr/16.1-2.271.

11. Schroth P. W. Financial leasing of equipment in the law of the United States. Uniform Law Review. 2011. Vol. 16. Is. 1-2. Pp. 437-467. https://doi.org/10.1093/ulr/16.1-2.437.

12. Han S., Wang W. An overview of the development of the financial leasing law in China. Uniform Law Review. 2011. Vol. 16. Is. 1-2. Pp. 241-270. https://doi.org/10.1093/ulr/16.1-2.241.

13. Goeringer P. Agricultural leasing in Maryland. 2013. $44 \mathrm{p}$. https://doi.org/10.2139/ssrn.2279617.

14. Дученко М. М., Павленко Т. В. Стан та перспективи розвитку лізингової галузі в Україні. Ефективна економіка. 2019. № 1. https://doi.org/10.32702/2307-2105-2019.1.53.

15. Васильчишин О., Тулай О. Лізинг в Україні: минуле і перспективи. Світ фінансів. 2006. Вип. 3. С. 128-141.

16. Ситник Н. С., Корень Д. О. Аналіз сучасного ринку фінансового лізингу України. Молодий вчений. 2019. № 5(69). С. 579-583. https://doi.org/10.32839/2304-5809/2019-5-69-125.

17. Васильєва Т. А., Бойко А. О., Кіріл'єва А. В. Перспективи розвитку вітчизняного ринку лізингових послуг в контексті трансформації фінансових відносин в Україні. Економічний простір. 2018. № 140. С. 14-26. https://doi.org/10.30838/P.ES.2224.261218.14.326.

18. Васильєва Т. А., Демчук К. С., Тютюник І. В. Роль та місце лізингу в системі фінансово-кредитного забезпечення підприємств. Економічний простір. 2018. № 139. С. 110-119.

19. Черевань I. В. Ефективність лізингу. Київ: НАН України; Фенікс, 2010. $168 \mathrm{c}$.

20. Іванишин В. В. Роль лізингу в забезпеченні сільськогосподарських підприємств засобами механізації. Київ: ІАЕ УААН, 2003. 294 с.

21. Іванишин В. В. Організаційно-економічні засади відтворення i ефективного використання технічного потенціалу аграрного виробництва: монографія. Київ: ННЦ «IAЕ», 2011. 350 с.

22. Дем'яненко М. Я., Іванина Ф. В. Стан державної фінансової підтримки сільського господарства. Агропромисловий комплекс України: стан, тендениї та перспективи розвитку / за ред. П. К. Канінського. Київ: ННЦ «ІАЕ», 2005. C. $233-235$.

23. Litvinova T. N. Agricultural lease as a perspective mechanism of development of infrastructure of entrepreneurship in the agricultural machinery market. The 21st Century from the Positions of Modern Science: Intellectual, Digital and Innovative Aspects. eds E. Popkova, B. Sergi. ISC 2019. Lecture Notes in 


\section{Agricultural and Resource Economics}

www.are-journal.com

Networks and Systems, vol. 91. Cham: Springer, 2020. Pp. 624-630. https://doi.org/10.1007/978-3-030-32015-7_70.

24. Пивовар П., Чайкін О., Дідух Д. Державна підтримка технічного оснащення екологічно орієнтованих сільськогосподарських підприємств. Agricultural and Resource Economics. 2017. Vol. 3. No. 1. Pp. 152-163. http://arejournal.com.

25. Захарченко В. І., Корсікова Н. М., Меркулов М. М. Інноваційний менеджмент: теорія і практика в умовах трансформації економіки. Київ: ЦНЛ, 2012. $448 \mathrm{c}$.

26. Динаміка лізингу в Україні майже вдвічі перевищує світову. URL: https://dailylviv.com/news/ekonomika/dynamika-lizynhu-v-ukrayini-maizhe-vdvichiperevyshchuie-svitovu-dyrektorka-u-lvovi-82087.

27. Підсумки діяльності фінансових компаній, ломбардів та юридичних осіб (лізингодавців). URL: https://www.nfp.gov.ua/ua/Informatsiia-pro-stan-irozvytok-finansovykh-kompanii-lizynhodavtsiv-talombardiv-Ukrainy.html.

28. Український ринок лізингу продовжує залишатися флагманом зростання на ринку фінансових послуг (підсумки за результатами 2019 р.). URL: http://uul.com.ua/2020/ukrayinskyj-rynok-lizyngu-prodovzhuye-zalyshatysyaflagmanom-zrostannya-na-rynku-finansovyh-poslug-pidsumky-za-rezultatamy-2019r.

29. Костецький Я. І. Лізинг як інструмент інвестиційно-інноваційного розвитку аграрного сектору економіки. Інноваційна економіка. 2016. № 1-2. C. 217-222.

30. Гудима О. В. Організаційно-економічний механізм лізингу сільськогосподарської техніки: автореф. дис. ... канд. екон. наук. Дніпропетровськ, 2005. 19 с.

\section{References}

1. Davidenko, N., Skrypnyk, H., Titenko, Z. and Zhovnirenko, O. V. (2019), Modeling of the optimum level of financial provision of Ukrainian enterprises' innovative activities. Global Journal of Environmental Science and Management, vol. 5, spec. is., pp. 197-205. https://doi.org/10.22034/gjesm.2019.05.SI.22.

2. Kirieieva, E. A., Pryshliak, N. V., Shamanska, O. I., Salkova, I. Yu. and Kucher, A. V. (2019), Strategic priorities and financial support of Ukrainian agricultural sector development. International Journal of Ecological Economics \& Statistics, vol. 40, no. 2, pp. 25-37.

3. Pronko, L., Furman, I., Kucher, A. and Gontaruk, Y. (2020), Formation of a state support program for agricultural producers in Ukraine considering world experience. European Journal of Sustainable Development, vol. 9, no. 1, pp. 364379. https://doi.org/10.14207/ejsd.2020.v9n1p364.

4. Sakhno, A., Polishchuk, N., Salkova, I. and Kucher, A. (2019), Impact of credit and investment resources on the productivity of agricultural sector. European Journal of Sustainable Development, vol. 8, no. 2, pp. 335-345. 
www.are-journal.com

https://doi.org/10.14207/ejsd.2019.v8n2p335.

5. Vnukova, N. N. (2005), The current state of economic and legal regulation of financial leasing in Ukraine. Lizynh v Ukraini, no. 3. pp. 8-10.

6. Sabluk, R. P. (2000), Theoretical aspects of leasing relations. Ekonomika APK, vol. 11, pp. 49-57.

7. Kuznecova, A. Y. and Levchenko, O. A. (2017), The methodological approaches to classification of leasing. Financial and credit activity: problems of theory and practice, vol. 1, no. 22, pp. 19-26. https://doi.org/10.18371/fcaptp.v1i22.109735.

8. Frignani, A. and Torsello, M. (2011), Financial leasing in Italy. Uniform Law Review, vol. 16, is. 1-2, pp. 351-371. https://doi.org/10.1093/ulr/16.1-2.351.

9. Inceoğlu, M. M., and Başoğlu, B. (2011), Financial Leasing in Turkey in Light of Recent Developments. Uniform Law Review, vol. 16, is. 1-2, pp. 415-435. https://doi.org/10.1093/ulr/16.1-2.415.

10. Josipović, T. and Wang, W. (2011), Financial leasing in Croatia. Uniform Law Review, vol. 16, is. 1-2, pp. 271-289. https://doi.org/10.1093/ulr/16.1-2.271.

11. Schroth, P. W. (2011), Financial Leasing of Equipment in the Law of the United States. Uniform Law Review, vol. 16, is. 1-2, pp. 437-467. https://doi.org/10.1093/ulr/16.1-2.437.

12. Han, S. and Wang, W. (2011), An overview of the development of the financial leasing law in China. Uniform Law Review, vol. 16, is. 1-2, pp. 241-270. https://doi.org/10.1093/ulr/16.1-2.241.

13. Goeringer, P. (2013), Agricultural leasing in Maryland. https://doi.org/10.2139/ssrn.2279617.

14. Duchenko, M. M. and Pavlenko, T. V. (2019), Leasing in Ukraine: state and development prospects. Efektyvna ekonomika, vol. 1. https://doi.org/10.32702/23072105-2019.1.53.

15. Vasyljchyshyn, O. and Tulaj, O. (2006), Leasing in Ukraine: past and prospects. World of Finance, vol. 3. pp. 128-141.

16. Sytnyk, N. and Koren, D. (2019), Perspectives for financial leasing in Ukraine. Young Scientist, vol. 5(69), pp. 579-583. https://doi.org/10.32839/23045809/2019-5-69-125.

17. Vasilieva, T., Boiko, A. and Kirilieva, A. (2018), Prospects of domestic leasing services market development in the context of transformation of financial relationships in Ukraine. Economic scope, vol. 140, pp. 14-26. https://doi.org/10.30838/P.ES.2224.261218.14.326.

18. Vasilieva, T., Demchuk, K. and Tiutiunyk, I. (2018), Role and place of leasing in financial and credit support of enterprises. Economic scope, vol. 139, pp. 110-119. https://doi.org/10.30838/ P.ES.2224.271018.110.277.

19. Cherevan, I. V. (2010), Efektyvnist lizynhu [Leasing efficiency], NAS of Ukraine, Feniks, Kyiv, Ukraine.

20. Ivanyshyn, V. V. (2003), Rol lizynhu v zabezpechenni silskohospodarskykh pidpryiemstv zasobamy mekhanizatsii [The role of leasing in the provision of 
agricultural enterprises means of mechanization], IAE UAAN, Kyiv, Ukraine.

21. Ivanyshyn, V. V. (2011), Orhanizatsiino-ekonomichni zasady vidtvorennia $i$ efektyvnoho vykorystannia tekhnichnoho potentsialu ahrarnoho vyrobnytstva [Organizational and economic basis of reproduction and effective use of the technical potential of agricultural production], NSC «IAE», Kyiv, Ukraine.

22. Demyanenko, M. Ja. and Ivanyna, F. V. (2005), Status of state financial support for agriculture in Aghropromyslovyj kompleks Ukrajiny: stan, tendenciji ta perspektyvy rozvytku [Agro-industrial complex of Ukraine: state, tendencies and prospects of development], ed. P. K. Kaninskyi, NSC «IAE», Kyiv, Ukraine.

23. Litvinova, T. N. (2020), Agricultural lease as a perspective mechanism of development of infrastructure of entrepreneurship in the agricultural machinery market in The 21st Century from the Positions of Modern Science: Intellectual, Digital and Innovative Aspects, eds E. Popkova, B. Sergi. ISC 2019. Lecture Notes in Networks and Systems, vol.91. Springer, Cham, Switzerland. https://doi.org/10.1007/978-3-030-32015-7_70.

24. Pyvovar, P., Chaikin, O. and Didukh, D. (2017), State support of technical provision of ecologically oriented agricultural enterprises. Agricultural and Resource Economics, vol. 3, no. 1, pp. 152-163. http://are-journal.com.

25. Zakharchenko, V. I., Korsikova, N. M. and Merkulov, M. M. (2012), Innovatsiinyi menedzhment: teoriia i praktyka $v$ umovakh transformatsii ekonomiky [Innovation management: theory and practice in the conditions of economic transformation], TsUL, Kyiv, Ukraine.

26. The dynamics of leasing in Ukraine is almost twice as high as in the world, available at: https://dailylviv.com/news/ekonomika/dynamika-lizynhu-v-ukrayinimaizhe-vdvichi-perevyshchuie-svitovu-dyrektorka-u-lvovi-82087.

27. Results of activity financial companies, pawnshops and legal entities (lessors), available at: https://www.nfp.gov.ua/ua/Informatsiia-pro-stan-i-rozvytokfinansovykh-kompanii-lizynhodavtsiv-talombardiv-Ukrainy.html.

28. The Ukrainian leasing market continues to be the flagship of growth in the financial services market (results of 2019), available at: http://uul.com.ua/2020/ukrayinskyj-rynok-lizyngu-prodovzhuye-zalyshatysyaflagmanom-zrostannya-na-rynku-finansovyh-poslug-pidsumky-za-rezultatamy-2019r.

29. Kostetskyi, Ya. I. (2016), Leasing as a tool for investment and innovation development of the agrarian sector of the economy. Innovative economy, vol. 1-2, pp. 217-222.

30. Gudyma, O. V. (2005), Organizing-economic mechanism of the leasing of the farm machinery, Abstract of $\mathrm{Ph}$. D. dissertation, Agrarian economics and agrarian-industrial complex, Dnipropetrovsk's State Agrarian University, Dnipropetrovsk, Ukraine. 
How to cite this article? Як цитувати цю статтю?

Стиль-ДСТУ:

Пащенко Ю. Стан і перспективи функціонування ринку лізингових послуг у сільському господарстві. Agricultural and Resource Economics. 2020. Vol.6. No. 2. Pp. 91-107. URL: http://are-journal.com.

Style-Harvard:

Pashchenko, Yu. (2020), State and prospects of functioning of the market of leasing services in agriculture. Agricultural and Resource Economics, vol. 6, no. 2, pp. 91-107, available at: http://are-journal.com. 